\title{
the Graduate Academic Journal
}

\section{of the Boston College School of Theology and Ministry}

Lumen et Vita has decided to provide a recommended reading list that may serve not only as a source for personal and academic edification, but also to provide students interested in submitting book reviews to future volumes of the journal with ideas. Professors were asked which books are newer and important, underappreciated, or still shape theological discussions today and should be read by all graduate students. The following is the 2012 list. Note: there will be some duplication as some professors recommended the same books.

Dick Clifford

- Brendan Byrne, A Costly Freedom: A Theological Reading of Mark's Gospel. , Lifting the Burden: Reaching Matthew's Gospel in the Christian Church. The Hospitality of God: A Reading of Luke's Gospel.

- These three are a fine blend of commentary and contemporary reflection, perfect for sermon preparation and for personal prayer.

- Gabriel Josipovici, The Book of God: A Response to the Bible.

○ Josipovici, born of Romano-Levantine Jewish parents, taught for many years at the University of Sussex. He has published over a dozen novels, a number of plays, three volumes of short stories, and a number of critical books. This is the freshest and most interesting "literary" approach to the Bible I have read, with perceptive appreciation of biblical style and irony.

- Naguib Mahfuz, The Cairo Trilogy.

○ Written about three decades ago by another Nobel laureate, and in various editions. A profound and sometime critical look at the history of a Muslim family in Cairo over several generations. Offers great insight into Islam.

- Sigrid Undset, Kristin Lavransdatter, translated by Tina Nunnally, 2005.

- Undset, a convert to Catholicism and winner of the 1928 Nobel Prize for literature, brings her knowledge of medieval Norway and novelist's eye to the story of a strong, complex, and deeply Christian woman. It's long, but every page is vivid and full of understanding. If you want to see how Christianity works in a particular society, read this novel. The translation is a huge advance over the widely used standard one.

- N. T. Wright, Jesus and the Victory of God.

- The second of Wright's probing, yet simple, synthetic work on the gospels. Wright excels in bringing the Old Testament to bear on the New. The book is fat because he explains everything. If you already know what he's talking about, skip to the next section. 
Dominic Doyle

- Michael Buckley, Denying and Disclosing God: The Ambiguous Progress of Modern Atheism.

- An excellent analysis of modern atheism that gives some thought-provoking strategies for how to respond.

- David Burrell, Knowing the Unknowable God: Ibn-Sina, Maimonides, Aquinas.

- A great study of medieval interreligious dialogue that sheds much light on the perennial theological question of how humans may come to know the divine.

- Michael Kirwan, Discovering Girard.

- One of the best introductions to Girard's extraordinary reflections on sociology and literature that have important consequences for how Christians understand atonement.

Christopher Frechette

- Jon Douglas Levenson, Creation and the persistence of evil: The Jewish drama of divine omnipotence.

- Gerald G. May, Addiction and grace.

Thomas Groome

- Congregation for the Clergy, The General Directory for Catechesis.

$\circ$ This is an excellent document and represents the official "mind of the Church" regarding religious education and catechesis.

- Thomas Groome, Will There Be Faith? A New Vision for Educating and Growing Disciples.

○ This is a capstone to my own books and essays across the years. Though this may sound self-serving, ask a faculty person in my field in any other university and most would recommend it.

- Jane Regan, Educating for an Adult Church.

Daniel Harrington

- Raymond E. Brown, Introduction to the New Testament.

- Larry Hurtado, Lord Jesus Christ.

- Wayne Meeks, The First Urban Christians.

Mark Massa

- David Hollenbach, Claims in Conflict.

- Elizabeth Johnson, She Who Is.

- James Keenan, Goodness and Rightness in Thomas Aquinas.

- Christian Smith, Soul Searching.

- Charles Taylor, A Secular Age.

- Terrence Tilley, The Disciples Jesus.

- David Tracy, The Analogical Imagination. , Blessed Rage for Order.

Thomas Massaro

- Robert Bellah et al., Habits of the Heart.

- Still the best single volume exploring the dominant moral languages and orientations prevalent within American culture, with its intriguing and unique mix of individualism and social commitment. 
- William James, Varieties of Religious Experience.

- Although over one hundred years old now, this book explores the intersection of religion and the (then) new field of psychology in an intriguing way, displaying at once its author's pragmatism, empiricism yet respect for the mysterious dimensions of the spiritual.

- H. Richard Niebuhr, Christ and Culture.

- A ground-breaking work from the middle of the last century that describes and explicates the major patterns by which religion and secular culture intersect, with important implications for social ethics and church-state relations.

Hosffman Ospino

- Augustine, Confessions.

- Benedict, The Rule of Saint Benedict.

- Ignatius, The Autobiography of St. Ignatius of Loyola. , Spiritual Exercises.

- Congregation for the Clergy, General Directory for Catechesis.

- Virgilio Elizondo, Galilean Journey: The Mexican-American Promise. , Guadalupe: Mother of the New Creation. , The Future is Mestizo: Life Where Cultures Meet.

- Paulo Freire, Pedagogy of the Oppressed.

- Roberto Goizueta, Caminemos Con Jesus: Toward a Hispanic/Latino Theology of Accompaniment.

- Thomas Groome, Sharing Faith: A Comprehensive Approach to Religious Education and Pastoral Ministry the Way of Shared Praxis.

- Gustavo Gutiérrez, A Theology of Liberation: History, Politics, and Salvation.

- Ada María Isasi-Díaz, En La Lucha/In the Struggle: Elaborating a Mujerista Theology.

Nancy Pineda-Mardrid

- Augustine, Confessions, translated by Rex Warner, 2001.

- Elizabeth A. Johnson, She Who Is: The Mystery of God in Feminist Theological Discourse.

- Roberto S. Goizueta, Caminemos Con Jesús: Toward a Hispanic/Latino Theology of Accompaniment.

Randy Sachs

- Athanasius, On the Incarnation.

- Augustine, Confessions.

- Thomas Aquinas, Summa Theologiae I, Q. 1-43.

- Hans Urs von Balthasar, Glory of the Lord: A Theological Aesthetics, vol.1, Seeing the Form.

- Louis Marie Chauvet, Sacrament and Symbol: A Sacramental Reinterpretation of Christian Experience.

- Yves Congar, True and False Reform in the Church.

- Roger Haight, Dynamics of Theology.

- Elizabeth A. Johnson, Quest for the Living God: Mapping Frontiers in the Theology of God. 
- Walter Kasper, Jesus the Christ. , The God of Jesus Christ.

- Hans Küng, The Church.

- Catherine Mowry LaCugna, God for Us: The Trinity and Christian Life.

- Martin Luther, Freedom of the Christian.

- John O'Malley, What Happened at Vatican II.

- Karl Rahner, Foundations of Christian Faith.

- Jon Sobrino, Christ the Liberator.

- David Tracy, The Analogical Imagination: Christian Theology and the Culture of Pluralism.

Thomas Stegman

- Rudolf Bultmann, Theology of the New Testament, 2 vols.

- James D.G. Dunn, The New Perspective on Paul.

- N.T. Wright, Jesus and the Victory of God. 